\section{Kastamonu Eğitim Dergisi Kastamonu Education Journal}

Eylül 2019 Cilt:27 Sayı:6

kefdergi.kastamonu.edu.tr
Başvuru Tarihi/Received: 16.09 .2018

Kabul Tarihi/Accepted: 17.02.2019

DOI: $10.24106 /$ kefdergi.3337

\title{
Sayı Konusmalarının Diskalkulik Ortaokul Ögrencilerinin Sayı Duyularına
} Etkisi $^{1}$

\section{The Effect of Number Talks on Number Senses' of Dyscalculic Middle School Students'}

\section{Öz}

\author{
Müyesser ÖZTÜRK², Burcu DURMAZ ${ }^{3}$ Derya CAN ${ }^{4}$
}

Bu araştırmanın amacı matematik öğrenme güçlüğü yaşayan ortaokul öğrencilerine uygulanan sayı konuşmaları uygulamalarının bu öğrencilerin sayı duyusu gelişimlerine olan etkisini incelemektir. Bu amaçla 2016-2017 eğitim öğretim yılı 2. döneminde bir il merkezindeki Rehberlik ve Araştrma Merkezi (RAM) tarafindan özel öğrenme güçlüğü tanısı almıs 15 5-8. sınıf öğrencisi ile çalışıımıştır. Araştırmanın deseni tek gruplu ön test son test yarı deneysel desen olup sayı konuşmaları uygulamaları 3 hafta boyunca devam etmiştir. Araştırmanın verileri Can (2017) tarafindan geliştirilen "Sayı Duyusu Ölçeği (SDÖ)" ; Fidan (2013) tarafindan geliştirilen "Matematik Başarı Testi (MBT)" ve De Vos' (1992) tarafindan geliştirilip Olkun, Can ve Yeşilpınar (2013) tarafindan Türkçeye uyarlama çalışması yapılan "Hesaplama Performans Testi (HPT)" aracılı̆ııla toplanmıştır. Araştırmada kullanılan HPT öğrencilere uygulanacak olan MBT'nin sınıf düzeyini belirlemek; MBT öğrencilerin matematik öğrenme güçlüğü yaşayıp yaşamadıklarını tespit etmek ve SDÖ ise sayı konuşmaları uygulamalarının etkisini ortaya koymak amacıyla kullanılmıştır. Araştırma sonucunda, sayı konuşmaları uygulamalarının matematik öğrenme güçlüğü yaşayan ortaokul öğrencilerinin sayı duyusu ölçeğinden aldıkları puanları istatistiksel olarak anlamlı bir şekilde etkilediği görülmüştür. Buna göre sayı konuşmaları uygulamaları matematik öğrenme güçlüğü yaşayan öğrencilerin öğretmenleri tarafindan kullanılabilecek bir öğretim aracı olarak tavsiye edilebilir. Araştırma daha fazla öğrenci ile daha uzun süre, farklı eğitim kademelerinde yürütülerek matematikle ilgili diğer özelliklerin değişimi incelenebilir.

Anahtar Kelimeler: diskalkuli, sayı duyusu, sayı konuşmaları

\section{Abstract}

The purpose of this study is to examine the effect of the number talks in the development of number senses of the middle school students' with dyscalculia. For this purpose we studied 15 students from 5th to 8th grades who were diagnosed with a specific learning disability by a provincial Guidance and Research Center (GRC) during the second semester of the 2016-2017 academic year. The design of the study is a single group pre-test post test quasi-experimental design and the number talks examination was continued for a 3 week period of time. The data was gathered via "Number Sense Scale (NSS)" which was developed by Can (2017); "Mathematics Achievement Test (MAT)" which was developed by Fidan (2013) and "Tempo Test Rekenen (TTR)" which was developed by De Vos' (1992) and was adapted into Turkish by Olkun, Can and Yeşilpınar (2013). To determine the grade level of MAT to be applied to the students TTR was used, MAT was used to examine if students were experincing the difficulty of learning mathematics and NSS was used to investigate the effectiveness of the number talks. According to the findings of the research, it was seen that the number talks statistically significantly affected the students' scores which were taken from the number sense scale. From this findings, it can be suggested that number talks can be used by teachers for the students who have difficulties in mathematics. This study has some limitations such as the size of the group and the period of the number talks applications so further studies can be done with much more students in a longer period of time.

Keywords: dyscalculia, number sense, number talk

1. Bu çalışma 3-5 Kasım 2017 tarihleri arasında Konya'da düzenlenen I. International Symposium on Social Sciences and Educational Research sempozyumunda sözlü bildiri olarak sunulmuştur.

2. MEB, İzmir, Türkiye; https://orcid.org/0000-0003-1257-8793

3. Süleyman Demirel Üniversitesi, Eğitim Fakültesi, Matematik ve Fen Bilimleri Eğitimi Bölümü, Isparta, Türkiye; https://orcid.org/0000-0002-2788-434X

4. Mehmet Akif Ersoy Üniversitesi, Eğitim Fakültesi, Temel Eğitim Bölümü, Burdur, Türkiye; https://orcid.org/0000-0003-1257-8793

Atıf / Citation: Öztürk, M., Durmaz, B. \& Can, D. (2019). Sayı konusmalarının diskalkulik ortaokul ögrencilerinin sayı duyularına etkisi. Kastamonu Education Journal, 27(6), 2467-2480. doi:10.24106/kefdergi.3337 


\section{Extended Abstract}

Introduction Dyscalculia is a kind of learning disability, which affects arithmetical and mathematical skills mostly. Although it is as widespread as dyslexia, it is less known by teachers and parents than dyslexia. One of the reasons why math is more difficult for the children with dyscalculia than for the average students is the lack of number sense. In the literature number sense is defined as using numbers in a flexible manner; choosing the effective way for practical thinking and problem solving and creating non-standard solutions. The questions about number sense are used for diagnosing students with dyscalculia. Because the sense of number is a basic component of mathematical thinking and reasoning it is important to develop the dyscalculic students' number senses. Number talks is an effective and useful instructional tool for developing number sense in all grades and it is known that the appropriate interventions made for these students have positive effects generally. Although there are many studies on the diagnosis of dyscalculia, research on effective instructional techniques that can be used for overcoming this learning difficulty is unfortunately limited. These studies are about number sense and dyscalculia but we did not encounter such a study that was investigated the effect of the number talks in the development of the dyscalculic students' number senses. So in this study our problem statement is "What is the effect of the number talks in the development of the number senses of the elementary school students with dyscalculia (mathematical learning disability)?".

Method For this purpose we studied with 15 elementary school students with dyscalculia from 5th to 8th grades. In the study group there are 5 students from 5th grade; 3 students from 6th grade; 2 students from 7th grade and 5 students from 8 th grade. We used purposive and convenience sampling methods. The criteria for selecting study group were being diagnosed with a learning disability by the Guidance and Research Center (GRC) and being a student in 5th-8th grades. Because there was not a special test or scale for diagnosing dyscalculia in GRCs. The design of the research is a single group pre-test post-test quasi-experimental design. The number talks experiment was continued for 3 weeks during the second semester of the 2016-2017 academic year. The data was gathered via "Number Sense Scale (NSS)", "Math Achievement Test (MAT)" and "Calculation Performance Test (Tempo Test Rekenen-TTR)". TTR and MAT tests were used for investigating whether the students have dyscalculia or not. NSS was used for examining the impact of the number talks intervention on the development of the number senses of the dyscalculic students. The researchers scored TTR and MAT individually thus the reliability of scoring was provided. The reliability coefficient of NSS was calculated for pre-test and post-test as .694 and .702 respectively. The difference scores of pre-test and post-test obtained from NSS were not normally distributed. For this reason, Wilcoxon Signed Ranks test, which is a non-parametric test, was used to compare pre-test and post-test scores. The results of Wilcoxon Signed Ranks test which was conducted in order to show whether the number talks produced a statistically significant difference between the pre-test and post-test NSS scores, a statistically significant difference was observed $[\mathrm{z}=-3.407, \mathrm{p}<.01]$. Since the difference is in favor of the post-test, it can be said that the applications of number talks have a statistically significant and positive effect on the NSS scores of elementary school students who have a difficulty in learning mathematics.

Results It can be said that this finding of this research is similar to the findings of the other studies in the literature. From this finding, number talks can be used as a useful and an effective instructional tool by the teachers for the students who have difficulties in math. If appropriate interventions are made for these students it can be said that positive changes in their cognitive and affective characteristics related to math will become real. It is a fact that the importance and value of appropriate interventions for the dyscalculic students is necessary. When the limitations of this research are assessed, it will be seen that the research has been carried out in a short period of time (because of the students' lack of motivation and another reasons), on the same level of education and with a small study group. Further studies can be done with much more students in a longer period of time. In addition, the long-term or permanent consequences of interventions for students with math learning difficulties and the changes in their cognitive and affective characteristics, such as attitudes toward math, self-concept and motivation, etc. can be examined. 


\section{Giriş}

Öğrenme güçlükleri günlük yaşama dair önemli becerilerle ilgili alanlarda karşımıza çıkmakta (Büttner ve Hasselhorn, 2011) ve meslek seçimine kadar pekçok önemli kararı etkileyebilmektedir (Wadlington, Wadlington ve Rupp, 2006). Meslek seçiminin temel aşamalarından biri olan üniversiteye girişte tüm dünyada önemli bir ölçüt olarak kullanılan matematik dersi özelinde yaşanan zorluğu ifade eden diskalkuli; disleksi ve disgrafi gibi öğrenme güçlüklerinden olup (Hannell, 2013) toplumda görülme sıklığı \% 3 ila 6 civarında değişmektedir (Butterworth, 2010; Price ve Ansari, 2013; Shalev ve Gross-Tsur, 2001). Sayı körlüğü olarak da bilinen (Guillemot, 2002) bu güçlük yaş, eğitim düzeyi ve zeka ile matematik performansının tutarsızlığı (Mutlu, 2016) ve doğuştan gelen ve belirli hesaplamaları yapmaktaki zorluk olarak tanımlanmaktadır (Pellerone, 2013). Diskalkuli, disleksi kadar yaygın görülmesine rağmen ne yazık ki öğretmenler ve aileler tarafindan disleksiye göre daha az bilinmektedir (Ardilla ve Roselli, 2002; Fu ve Chin, 2017; Sezer ve Akın, 2011). Diskalkulik öğrenciler dislekside olduğu gibi sayıları ters veya yer değiştirmiş bir şekilde yazıp basit matematiksel işlemleri yapmakta ve çok basamaklı sayıları okumakta da zorlanırlar (Salman, Özdemir, Salman ve Özdemir, 2016; Shalev ve Gross Tsur, 2001). Bird (2009) çok küçük miktarlarda bile şipşak sayılama yapamama, yani belli sayıdaki çoklukları sayma yapmadan algılayamama (subitise); verdiği cevabın mantıklı olup olmadığını tahmin edememe; hem kısa hem de uzun süreli hafizada zayıflık; geriye doğru sayamama; görsel ve uzamsal oryantasyon (orientation); yönleri karıştırma (sağ-sol); matematiksel etkinliklerde yavaş ilerleme; sıralamada zorluk; örüntüleri fark etmeme eğilimi; paralarla ilgili zorluklar; saat okumayı öğrenmede gecikme ve günlük yaşamda zamanı yönetmede zorluk gibi durumların diskalkuli göstergesi olarak düşünülebileceğini belirtmiştir. Diskalkulik öğrencilerin sayılar konusunda yaşadıkları zorluklar basamak değeri ve dört işlem gibi temel sayı kavramlarını anlamakta güçlük çekme; sayı değeri ve sayılar arası ilişkileri kullanma gibi sayıları sezgisel olarak kavrama eksikliği yaşama; çarpım tablosu gibi sayı gerçeklerini öğrenme, anımsama ve hızlıca kullanma ve uzun bölme işlemi gibi işlemlerde sorun yaşamadır. Bu tür öğrenciler doğru cevaba ulaşsalar ya da doğru yöntemi kullansalar bile bunu mekanik olarak yaptıklarından cevaplarının doğruluğundan da emin olamamaktadırlar (Chinn, 2004). Küçük çocuklarda gözlemlenebilecek parmak kullanarak işlem yapma ise diskalkulik öğrencilerde kalıcı olabilmekte, dolayısıyla farklı stratejiler üzerinde çalışılmasına rağmen ısrarla parmak kullanarak sayma da bu öğrenme güçlüğü için bir gösterge olarak düşünülmektedir (Emerson ve Babtie, 2010).

Sayılara ilişkin temel bilgi ve beceriler üzerinde yaşanan zorluklar hesaba katıldığında, matematiğin diskalkulik öğrencilere diğer öğrencilerden daha zor gelmesinin nedenlerinden birisi öğrencilerin sayı duyularının yeterince gelişmemesi ile açılanabilir (Hannell, 2013). Örneğin, Gray ve Tall (1994) tarafindan yapılan bir araştrrma projesinde araştrrmacılar 7-13 yaş aralığında düşük ve yüksek başarı düzeyindeki öğrencilerin sayı duyusu kullanımları arasında önemli farklııklara rastlamışlardır. Araştırma sonucunda, yüksek başarı düzeyindeki öğrencilerin 19+7, 21-16 gibi soruları çözerken 20+6, 20-15 şeklinde dönüşüm yapabildiği, fakat düşük başarı düzeyindeki öğrencilerin hiçbirinin sayı duyusunu kullanmadığı görülmüştür. Çalışma sonucunda araştırmacılar öğrencilerin başarı düzeylerinin düşük olmasının nedenini daha az bilmelerine değil sayıların esnekliğini kullanmamalarına bağlamıştır. Çünkü başarı düzeyi daha düşük olan öğrenciler sayılar arası esneklikten yararlanmak yerine matematiksel gerçekleri hatırlamaya çalışmakta, bu da onların matematiği daha zor öğrenmelerine yol açmaktadır (Gray ve Tall, 1994). Sayıları matematiksel süreçte mantiklı ve pratik bir şekilde kullanabilmek için gerekli olan sayı duyusu alanyazında, sayıları esnek bir şekilde kullanma; pratik düşünme ve problem çözme için etkin olan yolu seçme ve standart olmayan çözüm yolları yaratma olarak tanımlanmaktadır (Kayhan Altay ve Umay, 2013; McIntosh, Reys \& Reys, 1992; Reys, Reys, McIntosh, Emanuelsson, Johansson \& Yang, 1999). Yine bu tanımdan yola çıkılarak sayı duyusu gelişmiş olan bireylerin aksine diskalkulik bireylerin günlük yaşam için gerekli olan hesapları kolay ve akıcı bir şekilde yapamadığı için zorluk yaşayacağı çıkarımı yapılabilir (Alkaş Ulusoy ve Şahiner, 2017; Bayram, 2013). Sayı duyusunun gelişimi bireyin matematik geçmişiyle ilişkili olduğundan zayıf bir matematik eğitiminin de matematik öğrenme güçlüğüne neden olabileceği alanyazında da ele alınmaktadır. Örneğin yaşları 11-85 arasında değişen 10.000 'den fazla katlımcı ile yürütülen bir araştırmada sayı duyusunun okulda geçen süre ve yaşla bağlantılı olarak geliştiği ve 30 'lu yaşların sonlarında zirveye ulaştığı bulunmuştur. Bu kademeli artişın aksine aynı yaşta olan katılımcıların sayı duyuları arasında çok fazla farkın olması ise okul yıllarındaki matematiksel performansla ilişkilendirilmiştir. Araştırmanın sonunda ise sayı duyusunu hedef alan çalışmaların potansiyeli üzerinde durulmuştur (Halberda, Wilmer, Naiman ve Germine, 2012). Diskalkulik öğrencilerin de zorluk yaşadıkları konulardan biri olan temel sayı becerilerinin sayı duyusunun gelişimiyle bağlantılı olduğu söylenebilir. Her ne kadar tanılama için yaygın olarak kullanılan yaklaşıma uygun olan bilgisayar tabanlı nokta karşılaştırma, sayı karşılaştırma ve zihinsel sayı doğrusu testlerinde diskalkuli olan ve olmayan öğrenciler arasında reaksiyon zamanı ve doğru cevap yüzdesi açısından anlamlı bir fark bulunmamış olsa da (Çelikağ, 2015) diskalkuli tanılama testlerinde sayı duyusunu oluşturan bileşenlere dair soruların yer alması bu durumun bir göstergesidir. Yine düzenli olarak verilmiş noktaların sayısını hızlı bir şekilde 
belirlemede yaşanan zorluk okul çocukları için matematik öğrenme bozukluğunun bir belirtisi olarak görülmektedir (Landerl, Bevan ve Butterworth, 2004; Reeve ve Humberstone, 2012). Aynı şekilde sayı duyusu ve basamak değerine ilişkin yaşanan zorluklar işlemsel becerilerle ilgili problemlerle bir araya geldiği zaman öğrenme güçlüğüne sahip olan öğrencileri belirlemede kullanılan ipuçlarıdır (Ho, Wong ve Chan, 2015). Dolayısıyla matematik öğrenmek için gerekli olan ana becerilerin içerisinde yer alan sayı duyusu uzun süreli bellek, kısa süreli bellek, işleyen bellek ve kritik sayı ve kelime dizilerini öğrenme yeteneği kadar hayati bir role sahiptir. Çünkü matematik becerilerinin temeli, sayı duyusudur (Emerson ve Babtie, 2010) ve sayı duyusu matematik eğitiminin odak noktalarından biri olan problem çözme kadar önemli olup (NCTM, 2000) bu becerinin gelişimi için de adeta bir anahtar görevi görmektedir.

Diskalkulik öğrencilerin gelişimleri için yapılan müdahalelerden genellikle olumlu sonuç alındığı bilinmektedir (Chodura, Kuhn ve Holling, 2015). Bu çalışmalardan birinde rol oynama tekniğinin diskalkuli öğrencilerin akademik başarı ve sosyal uyumunu olumlu yönde etkilediği görülmüştür (Dorudian, 2011). Aynı şekilde psikolojik-eğitimsel müdahalelerin diskalkulik öğrencilerin akademik performansları üzerindeki etkisi yapılan bir metaanaliz çalışmasına göre yüksek çıkmıştır (Siadatian ve Ghamarani, 2013). Sayı duyusunun diskalkulik olan ve olmayan öğrencilerin matematik başarıları üzerindeki etkisinin incelendiği bir araştırmada üç ay boyunca 45-60 dakikalık setler halinde devam eden deneysel öğretimin deney grubunda yer alan diskalkulik olan ve olmayan öğrencilerin matematik başarılarını olumlu yönde istatistiksel olarak anlamlı bir şekilde etkilediği görülmüştür (Maryam, Mahnaz ve Hasan, 2011). Diskalkulik öğrenciler için tasarlanmış bir deneysel tanılayıcı değerlendirme programının matematik başarısına olan etkisi istatistiksel olarak anlamlı bulunmuştur (Rababah ve Alghazo, 2016). Yine bilgisayar tabanlı zenginleştirilmiş görsel bir oyun ortamının diskalkulik öğrencilerin matematik becerilerinin gelişimini olumlu yönde etkilediği görülmüştür (Castro, Bissaco, Panccioni, Rodrigues ve Domingues, 2014). Al-Makahleh (2011) öğrenme güçlüğü yaşayan 4. ve 5. sınıf öğrencilerine yapılan doğrudan öğretimin matematiğe yönelik tutum ve matematik başarısını olumlu yönde etkilediği sonucuna ulaşmıştır. Rajaie, Allahvirdiyani, Khalili ve Sadeghi (2011) ise dikkat eğitimi verdikleri diskalkulik öğrencilerin matematik performansında artış olduğunu gözlemlemiştir. Yapılan çalışmalarda diskalkulik öğrencilere yapılan müdahale çalışmalarında öğrencilerin olumlu cevap verdikleri ve gelişim gösterdikleri görülmektedir. Bu tür müdahalelerde oldukça başarılı sonuçlar alan bir kurumun (Emerson House) öğretimsel yaklaşımının ana hatları (Gifford ve Rockliffe, 2012) ise şu şekildedir: "Sayıları sayma ve yerleştirme; boş sayı doğruları ve boncuk dizileri; nokta örüntüleri şeklinde öğrenilen küçük sayılar; ekleme ya da çıkarma yapılarak oluşturulan sayı dizileri; nokta örüntüleri ile öğrenilen anahtar sayı dizileri; bağlantılı sayı üçlüleri; toplama ve çıkarma için 10'la bağlant kurma gibi akıl yürütme stratejileri; Dienes'in onluk tabanlarını kullanarak basamak değeri; sözel problemler; çarpma ve bölmeyi (paylaşma üzerine değil gruplamayı vurgulayarak) modelleme; anahtar çarpma gerçekleri (facts) ve bu gerçeklerden çıkarım yapma stratejileri; çarpma ve bölme için sözel problemler; standart yazım yöntemleri. Ölçme, para, şekiller ve kesirler ise daha sonra tanıtılmaktadır". Etkili olan bu müdahalelerin ortak noktasının öğretimsel sürecin matematiğin hiyerarşik yapısına uygun şekilde desenlenmesi olduğu görülmektedir. Öğretim sürecinde kompleks kavramlara geçmeden önce temel kavramların çok iyi anlaşılmasının gerektiği bilinen bir gerçektir (Gillum, 2014). Bu ilke göz önünde bulundurularak yapılan matematik öğretiminin, yapılan araştrma sonuçları da göz önüne alınırsa, hem normal hem de özel gereksinimli öğrenciler için daha faydalı olacağı düşünülebilir. Sayı konuşmaları uygulamaları da bu ilkeden yola çıkılarak öğrenci ihtiyaçlarına göre düzenlenebilmektedir.

Alanyazında sayı duyusu ve diskalkuli arasındaki ilişkileri; diskalkulik öğrencilerin matematiğe yönelik kaygılarını ve tutumlarını (Rubinsten ve Tannock, 2010); öğrencilerin yaşadıkları zorlukların giderilmesi için yapılan çeşitli müdahalelerin etkisini (Doğmaz, 2016; Mutlu, 2016; Ölmez ve Argün, 2017) inceleyen çalışmalar yer almaktadır. Ayrıca ülkemizde yapılan çalışmalarda, diskalkuli tanılama sürecinde kullanılabilecek model ve araçların geliştirildiği (Mutlu ve Akgün 2017), diskalkuli konusunda öğretmen görüşlerinin incelendiği (Hacısalihoğlu Karadeniz, 2013; Sezer ve Akın, 2011); özel gereksinimli öğrencilerin sayma becerileri ve matematik başarılarını geliştirmeye yönelik deneysel süreçlere yer verildiği (Mutlu, 2016; Doğmaz, 2016; Ölmez ve Argün, 2017) çalışmalara rastlamak mümkündür. Yapılan araştrrmalarda öğretmenlerin diskalkulik öğrencilerin özelliklerini fark etme ve gereksinimlerini karşılama yeterliklerinin ve okulların kaynaklarının istenen düzeyde olmadığı sonuçlarına varılmıştır (Chideridou-Mandari, Padeliadu, Karamatsouki, Sandravelis ve Karagiannidis, 2016; Hacısalihoğlu Karadeniz, 2013; Sezer ve Akın, 2011; Tuchura, 2016). Ayrıca diskalkulinin tanılanması üzerine yapılan birçok çalışma olmasına rağmen bu öğrenme güçlüğünü gidermek üzere kullanılabilecek etkili öğretimsel teknikler üzerine yapılan araştırmaların sayısı ne yazık ki çok azdır (Geary, 2006). Dolayısıyla diskalkulik öğrenciler için ders içinde ve dışında öğretimsel destek oluşturabilecek sayı konuşmalarının, bu öğrencilerin sayı duyuIarına olan etkisini incelemek hem alanyazına hem de eğitimcilere ve araşttrmacılara önemli katkı sağlayabilir. Öğretimsel bir araç olan sayı konuşmaları, bir matematik problemi dahilinde öğrencilerin problemle ilgili çözüm yolları bularak sınıfa cevaba nasıl ulaştıklarını açıklama sürecidir (Ruter, 2015). Sayılar üzerine konuşma, hesaplama becerileri ve zihinden hesabı geliştirmesinin yanında tüm sınıf seviyelerinde uygulanabilecek ve sınıf içi tartş̧ma ortamını destekleyecek bir araçtır (Flick ve Kuchey, 2015). Sayı konuşmaları yapılırken problem durumu öğrencilere sunulduktan sonra öğrenci- 
lere cevabı bulmaları için süre verilir. İkinci aşamada her öğrenci cevabını sınıfla paylaşır. Öğretmen tüm sınıfin cevabını aldıktan sonra öğrencilerden sorunun cevabını bulmak için kullanmış oldukları süreci anlatmalarını ister. Öğretmen bunu yaparken süreçle ilgili herhangi bir yorumda bulunmaz. Uygulamanın amacı süreç içerisinde öğrencilerin düşüncelerini gözden geçirerek doğru cevaba nasıl ulaşacaklarını anlamalarını sağlamaktı (Parish, 2014). Sayı konuşmaları uygulamalarında örneğin, öğretmen sınıfa 35+98 sorusunun cevabını sorar. Öğrencilere zihinden hesaplama yapmaları için birkaç dakika verilir. Öğretmen daha sonra öğrencilerden cevaplarını paylaşmalarını ister ve her bir cevabı yorum yapmadan tahtaya listeler. Öğrenciler daha sonra çözüm yollarını öğretmenleriyle ve sınıftaki diğer öğrencilerle paylaşır. Bu süreçte öğrencilerin doğru cevaba farklı çözüm stratejileri üzerinde tartı̧arak ulaşmaları sağlanır. Örneğin 63-27 işleminin sonucuna ulaşmak için birçok öğrenci sayıları alt alta yazarak algoritmaya dayalı çıkarma işlemi yapmayı tercih edebilmektedir. Fakat bu çözüm yolunu kullandıklarında öğrenciler basamak değeri kavramını içselleştirememekte ya da " 3 'ten 7 çıkmaz." gibi birtakım kavram yanılgılarına sahip olabilmektedir. Bu nedenle sayı konuşmaları öğrencilerin yaptıkları işlemleri anlamlandırmalarını sağlamakta önemli bir rol üstlenmektedir (Humphreys ve Parker, 2015). Sayılar üzerine konuşma uygulamasının sınıflarda gerçekleştirilmesi öğrencilerin sayılar arası ilişkileri dikkate almasını ve farkıı çözüm yolları geliştirmelerini sağlayabilir. Örneğin öğrenciler 63-27 işleminin sonucuna ulamak için 63'ten 30 çıkarıp 33 sayısının üzerine 3 ekleyebilirler ya da 63 ve 27 sayılarının üzerine 3 ekleyerek 66'dan 30'u çıkararak sonuca ulaşabilirler.

Matematik eğitiminin amacı öğrencileri matematikte iyi ya da kötü olarak etiketlemek değil onların güçlü yönlerini ve zorluk yaşadıkları özel alanları aydınlatmaktır (Dowker, 2004). Ayrıca ülkemiz matematik dersi öğretim programlarında da bunu destekleyecek şekilde herkesin matematik öğrenebileceği ilkesinden yola çıkılmıştır (MEB, 2009). Öğrenme sürecinde öğretmen desteğine diğer öğrencilerden daha fazla gereksinim duyan diskalkulik öğrenciler, müdahale edilmediği zaman yaşadıkları sürekli başarısızlık nedeniyle bilişsel zorlukların yanı sıra duygusal iyi oluşa kadar birçok konuda zarar görebilmektedirler (Bevan ve Butterworth, 2007; Zerafa, 2011). Butterworth ve Yeo (2004) bu tür öğrencilerin yaşadıkları güçlükle mücadele ettikleri halde öğrendiklerini unutarak başarısız oldukları için bir süre sonra tuvalete gitme, kalem açma vb. gibi kaçınma stratejileri geliştirerek matematik dersinden uzaklaştklarını belirtmiştir. Bu tür kaçınma davranışlarıyla birlikte öğrencilerin olumsuz tutumları matematik kaygısına ve hatta okul fobisine dönüşebilmektedir (Krinzinger ve Kaufmann, 2006; Akt: Kaufmann ve von Aster, 2012). Oysa önemli matematiksel zorluklar yaşayan öğrenciler çok uyaranlı bir yaklaşımla en iyi şekilde öğrenebilmektedir (Emerson ve Babtie, 2010). Bu durum gözönünde bulundurulduğunda, bu araştırmada sayı konuşmaları uygulamalarının matematik öğrenme güçlüğü yaşayan (diskalkulik) ortaokul öğrencilerinin sayı duyularına etkisini belirleyebilmek amaçlanmıştır. Böylece matematiksel öğrenme güçlüğü yaşayan öğrencilerin gerek öğretimsel hayatlarında gerekse günlük yaşantllarında önemli bir yeri olan sayı ve işlem becerilerini geliştirmek, sorulara farklı çözüm yolları bulabilmelerini sağlamak ve buldukları sonuçlar üzerinde düşünme ve bu sonuçları sorgulama becerilerini geliştirebilmek olarak belirlenmiş olup araştırmanın problem cümlesi "Sayı konuşmaları uygulamalarının (diskalkulik) matematik öğrenme güçlüğü yaşayan ortaokul öğrencilerinin sayı duyularının gelişimine etkisi nedir?" olarak belirlenmiştir.

\section{Yöntem}

Bu bölümde araştırmanın deseni, çalışma grubu, veri toplama araçları ve veri analizi ele alınmıştır.

\section{Araştırmanın deseni}

Araşttrmada matematik öğrenme güçlüğüne sahip (diskalkulik) ortaokul öğrencilerine yapılan sayı konuşmaları uygulamalarının bu öğrencilerin sayı duyularına olan etkisi ortaya konmaya çalışıldığından ön test son test tek gruplu yarı deneysel desen kullanılmıştır.

\section{Çalışma grubu}

Araştırmada toplumda daha az görülen diskalkulik öğrencilerin sayı duyularında meydana gelen değişim incelendiğinden amaçlı ve uygun örneklemeden yararlanılmıştr. Amaçlı örneklemede örneklem oluşturulurken araştırma kapsamına alınacak bireylere ait kriterler araştırmanın amacına göre araştırmacı tarafindan belirlenmektedir (İşçil, 1973). Bu örnekleme yoluna çalışmanın amacına bağlı olarak bilgi açısından zengin durumları ortaya çıkmasını sağlayan belirli ölçütleri taşıyan bireylerle çalışılması gerektiğinde gidilmektedir (Büyüköztürk, Kılıç Çakmak, Akgün, Karadeniz ve Demirel, 2012). Araştırmada öğrenme güçlüğü yaşayan öğrenciler tercih edildiği için çalışma grubuna dahil edilme kriteri il merkezindeki Rehberlik ve Araştırma Merkezi (RAM) tarafindan özgül öğrenme güçlüğü tanısı almış ortaokul öğrencisi olmak olarak belirlenmiştir. Özgül öğrenme güçlüğü tanısı konurken birçok test grubundan faydalanılmaktadır. Bunlardan en çok kullanılanları Wechsler Zeka Ölçeği, akademik başarı ve sağ-sol yön tayin testleridir (Erden, 2011). Daha sonra bu kriterleri sağlayan öğrencilerden araşttrmaya gönüllü olarak katılmak isteyen $15^{\prime}$ iyle çalışıldığından uygun örnekleme yapılmıştır. Başlangıçta RAM tarafindan özgül öğrenme güçlüğü tanısı alan 16 öğrenci olmasına rağmen 
7. sınıfa devam eden 1 öğrenci araştırmanın deneysel sürecine dahil edilecek öğrencilerin belirlenmesi için uygulanan testlerden (MBT ve HPT) yüksek performans gösterdiği; özgül öğrenme güçlüğü yaşadığı halde matematik öğrenme güçlüğü yaşamadığı için deneysel öğretim sürecine dahil edilmemiştir. Öğrencilerin sınıflara göre dağılımları şu şekildedir: 5 kişi 5.; 3 kişi 6.; 2 kişi 7. ve 5 kişi 8. sınıf. Araştırma için gerekli izinler ilgili kurumlardan, öğrenciler ve velilerinden alındıktan sonra araştırmaya başlanmıştır. Araştırmaya katılan öğrencilerle ilgili günlük gözlemler için notlar alınırken öğrencilerin isimleri yerine Ö1, Ö2... ve Ö16 şeklinde kodlama yoluna gidilmiştir.

\section{Veri toplama araçları}

Araştırmanın verileri Can (2017) tarafindan geliştirilen ve 10 adet sorudan oluşan "Sayı Duyusu Ölçeği (SDÖ)"; Fidan (2013) tarafindan ilkokul 1-4. sınıf düzeyinde tüm sınıf düzeylerinde geliştirilen ve her sınıf düzeyinde farklı sayıda soru bulunan "Matematik Başarı Testi (MBT)" ve De Vos' (1995) tarafından geliştirilip Olkun, Can ve Yeşilpınar (2013) tarafindan Türkçeye uyarlama çalışması yapılan "Hesaplama Performansı Testi (HPT)" ile toplanmıştr. Öğrencilerin matematiksel beceri açısından gerçekte ait oldukları sınıf düzeyini ve matematik öğrenme güçlüğüne sahip olup olmadığının tespiti için uygulanması gereken MBT'nin hangi sınıf düzeyine ait versiyonun uygulanması gerektiğine karar vermek için öncelikle HPT uygulanmıştır. Buradan çıkan sonuca göre öğrenciye MBT’nin ilgili sınıf düzeyine ait testi verilmiştir. HPT 5 kolondan meydana gelen bir test olup içerisinde dört işlemle ilgili alıştırmalar barındırmaktadır. Kolonlarda sırasıyla toplama, çıkarma, çarpma, bölme ve bu dört işlemi barındıran karışık işlemler bulunmaktadır. Bu kolonlardan ilkinde sadece toplamayla ilgili işlemler bulunmaktadır ve " $3+0 ; 13+4 ; 28+27$ " şeklindedir. ikinci kolonda ise yine aynı toplama işlemlerine ek olarak ve aynı sayıda çıkarma işlemi bulunmaktadır. Bu işlemler de "6-5; 18-6; 35-17" şeklindedir. Üçüncü kolonda eşit sayıda toplama, çıkarma ve çarpma işlemleri bulunmaktadır ve önceki kolonlara ek olarak burada "1x4; 10x4; 28x3" şeklinde çarpma işlemlerine yer verilmiştir. HPT'nin son kolonunda dört işlemin tamamına ait eşit sayıda soru bulunmaktadır ve bölme işlemleri de "9:3; 36:3; 42:14" şeklindedir. HPT’nin yanı sıra MBT özgül öğrenme güçlüğü olarak genel bir tanı alan bu öğrencilerin matematik öğrenme güçlüklerini belirlemek amacıyla kullanılabilecek bir test olduğu için (Fidan, 2013) araştrmada bu nedenle kullanılmıştır. MBT ise sayı sayma, sayı örüntüleri, dört işlem vb. gibi konuları içeren ilkokul 1-4. sınıf matematik dersi öğretim programı sayılar öğrenme alanına özgü geliştirilmiş bir başarı testidir. Bu testte ise 1. sınıf düzeyindeki bir öğrencinin cevaplaması için yer alan sorularda toplama ve çıkarma işlemini barındıran " $6+4+5=$ ?" ve "Ali'nin 6 tane kalemi var. 11 kaleminin olması için kaç tane daha kalem gerekir?" şeklinde alıştırma ve problemler yer almaktadır. 2. sınıf düzeyinde ise toplama, çıkarma ve çarpma işlemi ile birlikte, sıralama, basamak değeri bulmaya ilişkin alıştrma ve problemlere yer verilmiştir. "23+52=?"; "56-32=?"; "Metin her gün 9 saat uyumaktadır. 5 günün sonunda kaç saat uyumuş olur?"; "75 sayısındaki 7 rakamı hangi basamaktadır? Yazınız." ve "75, 55, 89, 76 sayılarını küçükten büyüğe sıralayınız" şeklindedir. 3. sınıf düzeyindeki sorular 2. sınıf düzeyine ek olarak bölme ve kesirlere ilişkin soruları da barındırmaktadır. Bu testte yer alan sorular " 475 sayısındaki rakamın basamak değeri kaçtr?”; "375; 532; 362 ve 482 sayılarını sembol kullanarak küçükten büyüğe doğru sıralayınız"; "52:4 işleminin sonucu kaçtır?" ve "Bir okuldaki kız öğrencilerin sayısı 425, erkek öğrencilerin sayısı ise kızların sayısından 53 fazladır. Okuldaki toplam öğrenci sayısı kaçttr?" şeklindedir. 4. sınıf düzeyindeki testte ise 3. sınıf testinde de yer alan konulara ilişkin sorular yer almaktadır. Testteki sorular ise "7308+269 işleminin sonucu kaçtır?"; "2136 x (16:8)=?” ve "1952 yılında doğan bir kişi 2012 yııında kaç yaşında olur?" şeklindedir. SDÖ ise sayı konuşmaları uygulamalarının etkisini ortaya koymak amacıyla hem öğretim süreci başında hem de sonunda ön test ve son test olarak uygulanmıştır. Öğrencilerin sayı duyuların ölçmeyi amaçlayan SDÖ’de yer alan sorular hem kural temelli hem de sayı duyusu temelli çözüm yolları kullanılarak çözülebilecek niteliktedir. Örneğin 91+93+97+99 işleminin sonucuna ulaşmak için öğrencilerin algoritmaya dayalı çözüm yolunu mu yoksa sayılar arası ilişkilerden yararlanarak (örneğin, 91+99=190, 93+97=190, 190+190=380) sayı duyusu temelli çözüm yolunu kullanmayı tercih ettiği yönündeki bulgular öğrencilerin sayı duyusu hakkında bilgi sağlayacaktır.

\section{Öğretim süreci}

Sayı konuşmaları uygulamalarından verim alabilmek için deneysel öğretim süreci her öğrenci ile haftanın aynı gün ve saatinde olacak şekilde birebir yürütülmüştür. Yapılan sayı konuşmaları oturumlarının her öğrenciyle birebir yürütülmesinin ve temel sayı becerileri üzerine kurgulanmasının nedeni alanyazındaki çalışmalardan elde edilen sonuçlardır. Çünkü bir metaanaliz çalışmasında temel sayısal becerilerinin öğretiminin problem çözme stratejileri öğretimine; kısa süreli çalışmaların uzun süreli olanlara ve birebir öğretmenle yürütülenlerin bilgisayar tabanlı olanlara göre daha etkili olduğu bulunmuştur (Kroesbergen, van Luit, 2003). Aynı şekilde tekrar eden çalışmaların, ana konunun bölümlere ayrılmasının, küçük gruplar ve strateji öğretiminde küçük ipuçlarının kullanılmasının diskalkulik öğrenciler için yapılan eğitimi daha etkili kıldığı (Swanson ve Sachse Lee, 2000) bilindiğinden bu koşullar sağlanmaya çalışılmıştr. Araştrma, öğrencilerin belirli bir süreden sonra (araştırma için de tamamlanan eğitim süresi olan 3 hafta) ilerleme kaydedemedikleri, tekrar eden başarısızık nedeniyle oturumlara çalışmanın başındaki motivasyonla devam etmek istemedikleri ve 
okullarında devam eden ders ve etkinliklerden uzun süre yoksun kalmamaları böylece arkadaşlarından soyutlanmamaları gerektiği düşüncesiyle öğrencilerin ilerleme kaydetmeyi bıraktı̆ı ana kadar yürütülebilmiştir. Bununla birlikte sayı konuşmalarının öğrencilerde bıkkınlık yaratmaması ve başarıya ulaşabilmesi için belirli sürelerle yapılması gerektiği bilgisi göz önünde bulundurulmuştur. Sayı konuşmaları uygulamalarını içeren öğretim sürecinin nasıl yürütüldüğüne dair detaylar aşağıda sunulmuştur:

Grup noktaları (en fazla 10 noktadan oluşan görseller) öğrencilere gösterilerek kaç tane olduğunun belirlenmesi istenmiştir. Öğrencilerin noktaları tek tek mi yoksa gruplama yaparak mı saydıklarına bakılmıştır. Bu işlem için 4 öğrenci dışında tüm öğrencilerin noktalar karışık bir şekilde olmadığı sürece üçerli veya beşerli gruplandırma yaptıkları karışık verilmiş noktalar ile karşılaştğında da ikişerli sayma yaptıkları gözlemlenmiştir. Dört öğrenci ise noktaları tek tek sayma yoluna gitmiştir. Bu 4 öğrenciden ikisinin aslında gruplandırma yaparak da sayabilecekleri ama yanlış cevap vermemek amacıyla tek tek sayma yapmayı tercih ettikleri gözlemlenmiştir. Başka bir örnekte öğrencilere belli bir gruptan oluşan noktalar (nokta sayısı 10'dan az olan) gösterilmiş ve "Toplamda 10 nokta olması için kaç tane nokta gerekiyor?" sorusu yöneltilmiştir. Bu soruya verilen cevaplar incelenirken de öğrencinin parmak sayarak mı yoksa şipşak sayılama yolu ile doğrudan üç cevabını verip veremediklerine-bakılmıştır. Bu aşamada bir öğrenci hariç öğrencilerin tamamının parmaklarını kullanarak cevap verdiği gözlemlenmiştir. Toplamaya ilişkin bir çalışmada ise örneğin; $3+6$ işlemi için öğrencinin 6'nın üzerine 3'ü ekleyerek mi, ilk toplananın üzerine diğerini mi eklediği yoksa 1,2,3,4,5,6 diyerek parmakla sayma yapıp 6'yı belirledikten sonra 1,2,3 şeklinde ilerleyerek 6'nın üzerine 3'ü mü eklediği incelenmiştir. Bu örnekte de öğrencilerin tamamı büyük sayının üzerine küçük sayıyı eklemiştir. 1+1, 2+2, 3+3 gibi ikililerin toplamı verilerek öğrencilerden zihinden toplama yapmaları istenmiş ve öğrencilerin bu toplamaları nereye kadar yapabildikleri incelenmiştir. 5+5'e kadar direkt söyleyen dört öğrenci, 7+7 toplamına kadar söyleyen bir öğrenci, 10+10 toplamına kadar direkt söyleyen dokuz öğrenci, $15+15$ toplamına kadar söyleyen ise bir öğrenci vardır ve bu öğrencilerin hepsinin sonu sıfir ile biten $(20+20,30+30$ toplamı gibi) tüm işlemleri rahatlıkla yaptıkları gözlemlenmiştir. En az 3 sayının toplamı olacak şekilde $(2+5+8)$ bir toplama işlemi verilerek öğrencilerin bu toplamayı nasıl yaptkları da bu süreçte incelenen kazanımlar arasındadır. Burada da toplama işlemini başta verilen sayıdan başlayarak mı yani $2+5+8$ diye mi devam ettikleri yoksa $8+2=1010+5=15$ yapıp parmakla sayma yapmadan mı devam ettiklerine bakılmıştır. Burada da öğrenciler sayının büyüklük ya da küçüklüğüne aldırmadan baştan başlayıp ve genellikle de parmaklarını kullanarak işlem yapmışlardır. Her bir öğrenciye ek olarak 2+5'i toplayıp 8 eklemenin dışında başka bir çözüm yolu olup olmadığı sorusu yöneltilmiştir. Onbeş öğrencinin sekizi 8 ile 2'yi topladıktan sonra 5 ekleme işlemini parmaklarını kullanmadan yapmışlardır. Bu süreç sonunda öğrenciler toplama işlemlerini yaparken önce toplamı on yapan sayıları bulup parmaklarını da kullanmadan toplama işlemini yapmayı başarmışlardır. Diğer yedi öğrenci ile de öncelikle hangi iki sayının toplamının on yaptı̆̆ı ile ilgili çalışmalar yapılmış ve beş öğrencinin toplamı on yapan sayı çiftlerini fark etmelerine rağmen yanlış yapmaktan çekinmeleri nedeniyle işleme baştan başlayıp parmak kullanarak saymaya devam ettikleri, iki öğrencinin ise parmaklarını kullanarak en baştan toplama işlemi yaptı̆ı̆ görülmüştür. Son aşamada 4+6 gibi basit düzeydeki toplama işlemlerinden başlanarak üçlü toplama $(4+6+8)$ ve iki basamaklı toplama işlemi $(35+29)$ olacak şekilde toplama işlemleriyle öğrencilerin sayıları ne kadar esnek kulandığına bakılmıştr. Sekiz öğrencinin bir basamaklı sayılarda üçlü, dörtlü ve beşli toplamada artk parmaklarını kullanmadan önce toplamı on yapan sayıları buldukları sonrasında zihinden toplama işlemi yapttkları gözlemlenmiştir. Bu öğrencilerle iki basamaklı sayılarda toplama işlemi üzerinde çalışıldığında ise alt öğrencinin iki basamaklı toplamalarla ilgili işlemleri yapamadıkları, ikisinin (örneğin 35+29 toplamı için 30+20+9+5 şeklinde) yapabildiği gözlemlenmiştir. Kalan yedi öğrenci ile de toplamı 10 yapan sayılar ve üçlü, dörtlü ve beşli toplama işlemleri üzerinde çalışılıp iki tanesinin hiçbir şekilde 10 yapanları fark etmeyip parmak sayarak işlem yaptğı̆ gözlemlenirken diğerlerinin de bazen on yapanı görmesine rağmen bazen de yanlış olmasın diye parmaklarını sayarak cevap verdikleri görülmüştür. Sayı konuşmaları uygulamaları yapılırken araştırmacı tarafindan her oturum sonrası öğrencilerin başlangıçtaki becerileri ve süreçte kazandıkları becerilere ilişkin gözlemlere ait kısa notlar alınmıştır. Her öğrenci için ayrı ayrı alınan notlar farklı sınıf düzeylerindeki öğrencilere örnek olacak şekilde Tablo 1'de verilmiştir. 
Tablo 1. Sayı konuşmaları uygulama sürecine ilişkin bazı notlar

\begin{tabular}{|c|c|c|c|}
\hline Öğrenci & Sınıf Düzeyi & Uygulama Öncesi & Uygulama Sırasında \\
\hline Ö1 & 5 & $\begin{array}{l}\text { Noktaların sayısını hemen fark etmesine rağmen yanlış } \\
\text { olmasın diye tek tek saydı. Sonucun } 10 \text { olduğu ikili toplam- } \\
\text { larda verilmeyeni bulmak için parmaklarını kullandı. 3+6 gibi } \\
\text { toplamları yaparken baştan saymadan büyük sayının üzerine } \\
\text { ekleme yaptı. Bir sayının kendisiyle toplamına ilişkin alıştır- } \\
\text { malardan sadece } 10+10 \text { işleminin sonucunu direk söyledi. Üç } \\
\text { toplananı olan toplamada baştan başlayarak toplama yapt. } \\
\text { Dönüşüm işlemlerini yaparken çok zorlandı. }\end{array}$ & $\begin{array}{l}\text { Üç toplananı olan toplamada } 10 \text { eden } \\
\text { toplamları fark ederek 10’un üzerine } \\
\text { ekleme yapmaya başladı. Çok kısa sürede } \\
\text { ve parmak kullanmaya ihtiyaç duymadan } \\
\text { toplama işlemi yapmaya başlayınca 5'li } \\
\text { toplamaları da yapmak istedi. Dönüşüm } \\
\text { işlemlerinde bir basamaklı işlemlerde ba- } \\
\text { şarılı oldu fakat iki basamaklılarda başarılı } \\
\text { olamadı. }\end{array}$ \\
\hline Ö6 & 6 & $\begin{array}{l}\text { Noktaları gruplandırarak saydı. Sonucun } 10 \text { olduğu ikili top- } \\
\text { lamlarda verilmeyeni bulmak için parmaklarını kullandı. 3+6 } \\
\text { gibi toplamları yaparken baştan saymadan büyük sayının üze- } \\
\text { rine ekleme yapt. Bir sayının kendisiyle toplamını doğrudan } \\
\text { bulabiliyorken diğer toplamlar için parmaklarını kullandı. Üçlü } \\
\text { toplamalarda toplamı } 10 \text { eden sayıları fark edemediği için } \\
\text { toplamı baştan başlayarak yapt. Dönüşüm işlemlerini ancak } \\
\text { parmaklarını kullanarak yapabildi. }\end{array}$ & $\begin{array}{c}\text { Üç toplananı olan toplamada } 10 \text { eden } \\
\text { toplamları fark ederek 10'un üzerine } \\
\text { ekleme yapmaya başladı. Dönüşüm işlem } \\
\text { lerinde bir basamaklı işlemlerde başarılı } \\
\text { oldu fakat iki basamaklılarda kafası karıştı } \\
\text { Bir basamaklı sayılarda çıkarmayı ancak } \\
\text { parmaklarını kullanarak yapabilir hale } \\
\text { geldi iki basamaklı sayılarla çıkarmayı ise } \\
\text { yapamadı. }\end{array}$ \\
\hline Ö8 & 7 & $\begin{array}{l}\text { Noktaları gruplayarak sayma yapt. Sonucun } 10 \text { olduğu ikili } \\
\text { toplamlarda verilmeyeni bulmak için parmaklarını kullandı. } \\
\text { 3+6 gibi toplamları yaparken baştan saymadan büyük sayının } \\
\text { üzerine ekleme yapt. Bir sayının kendisiyle toplamını doğru- } \\
\text { dan bulabiliyorken diğer toplamlar için parmaklarını kullan- } \\
\text { dı. Üçlü toplamalarda hangi sayıların toplamının } 10 \text { ettiğini } \\
\text { bilmediği için parmakla sayma yapt ve hatalı sonuçlara ulaşt. }\end{array}$ & $\begin{array}{c}\text { Toplamı } 10 \text { yapan sayıları fark edebildiği } \\
\text { için } 3 \text { ve } 4 \text { terimli toplama işlemlerini } \\
\text { parmaklarını hiç kullanmadan yapabildi. } \\
\text { Dönüşüm işlemlerini hiç yapamadı hep } \\
\text { parmaklarını kullandı. }\end{array}$ \\
\hline Ö12 & 8 & $\begin{array}{c}\text { Noktaları gruplayarak saydı. Sonucun } 10 \text { olduğu ikili toplamlarda } \\
\text { verilmeyeni bulmak için parmaklarını kullandı. 3+6 gibi toplamları } \\
\text { yaparken baştan saymadan büyük sayının üzerine ekleme yapt. Bir } \\
\text { sayının kendisiyle toplamını 10+10’a kadar sorunsuz yaptı. Ondan } \\
\text { sonra ise sayının sonu sıfırla bitiyorsa ( } 20+20 \text { gibi) doğrudan bula- } \\
\text { bildi. Üç toplananı olan toplamada baştan başlayarak toplama yaptı. } \\
\text { Dönüşüm işlemlerini yapamadı. }\end{array}$ & $\begin{array}{c}\text { Toplamı } 10 \text { yapan sayıları fark edebildiği için } \\
5 \text { terimli toplamaya kadar ilerledi. Dönüşüm } \\
\text { işlemlerini sayıların sonunu sıfir yapacak şekil- } \\
\text { de parçalamaya (örneğin } 45+46=40+40+5+6 \\
\text { gibi) ve toplamaya başladı. Çıkarma işleminde } \\
\text { bir basamaklılarda zihinden işlem yaparken } \\
\text { onluk bozmayı gerektiren işlemlerde başarılı } \\
\text { olamadı. }\end{array}$ \\
\hline
\end{tabular}

Tabloya bakıldığında çalışmaya katılan öğrencilerin, sınıf düzeyi fark etmeksizin benzer zorluklar yaşadıkları benzer hatalara düşebildikleri görülmektedir. İlerleyen sınıf düzeylerine rağmen parmak kullanarak işlem yapma ve bu olmaksızın verdiği cevaptan emin olamama, ilkokul matematik dersi öğretim programına ait kazanımlarda (örneğin, onluk bozmayı gerektiren çıkarma işlemi) yaşanan sorunlar vb. gibi durumların diskalkuli göstergelerinden olması ise dikkat çekicidir.

\section{Veri analizi}

HPT'de dört işlemle ilgili alıştırmalar sınıf düzeylerine göre dağılmaktadır. Buna göre sınıf düzeylerine göre sırasıyla 1. sınıf düzeyi için 20; 2 . sınıf düzeyi için $80 ; 3$. ve 4. sınıf düzeyleri için 200'er soru yer almaktadır. Bu testte yer alan her bir kolonu cevaplamak üzere $1 \mathrm{dk}$ süre verilmektedir (Olkun, Can ve Yeşilpınar, 2013). HPT'nin değerlendirme kriteri 1. sınıf için 10 doğru ve üzeri; 2 . sınıf için 28 doğru ve üzeri; 3 . sınıf için 82 doğru ve üzeri ve 4 . sınıf için 97 doğru ve üzeri şeklindedir (Olkun, 2015; S. Olkun, görüşme, 13 Mart 2017). Örneğin bu sınıf düzeylerinde sırasıyla 15, 30, 50 ve 60 doğru yapan bir öğrencinin seviyesi 2. sınıf olarak değerlendirilmektedir. HPT sonuçları ele alındıktan sonra öğrencilerin bu testten elde ettikleri puanlara göre her bir öğrenci için uygulanması gereken MBT'nin sınıf düzeyleri belirlenmiştir. Yani HPT, öğrencilerin matematik öğrenme zorluğu yaşayıp yaşamadıklarını test etmek üzere kullanılacak olan MBT'nin ön koşul testi olarak kullanılmıştır. Bu testte 1-4. sınıf matematik dersi öğretim programına göre 1 . sınıf için $13 ; 2$. sınıf için 15; 3. sınıf için 16 ve 4. sınıf için 24 soru yer almaktadır. Öğrencilerin MBT'den elde ettikleri puanlar Fidan (2013) tarafindan oluşturulan puanlama anahtarına göre puanlanmış olup sınıf düzeyini belirlemek üzere kullanılan kriterler 1. sınıf için 7 doğru ve üzeri; 2 . sınıf için 8 doğru ve üzeri; 3. sınıf için 9 doğru ve üzeri ve son olarak 4 . sınıf için 15 doğru ve üzeridir. Örneğin bir öğrenci 4. sınıf düzeyindeki sorular için kriter olan 15 doğrunun altında kaldı fakat 3. sınıfin kriterini sağladıysa sınıf düzeyi 3 olarak belirlenmektedir. HPT ve MBT bağımsız iki araştırmacı tarafindan puanlama anahtarına göre ayrı ayrı puanlanmış ve puanlama güvenirliği sağlanmaya çalışılmıştır. Veri toplama araçlarının sonuncusu olan SDÖ'de (Can, 2017) yer alan soruların tamamı ölçeğin kendisinde de olduğu şekliyle yani doğru cevaplar 1 yanlış 
cevaplar 0 puan olacak şekilde puanlanmıştr. Ön test ve son test olarak uygulanan SDÖ'nün K-20 güvenirlik katsayısı sırasıyla .694 ve .702 olarak hesaplanmış ve ölçümlere ilişkin güvenirlik katsayılarının bulundukları değer aralığı itibari ile oldukça güvenilir (Can, 2013) olduğu görülmüştür.

\section{Bulgular}

Bu bölümde araşttrmadan elde edilen bulgulara ve yorumlara yer verilmiştir.

\section{Veri toplama araçlarından elde edilen bulgular}

Sayı konuşmaları uygulamasına geçmeden önce öğrencilere uygulanması gereken MBT'den öğrencinin seviyesine uygun olanın seçimi için yapılan HPT'ye ilişkin sonuçlar Tablo 2'de verilmiştir.

Tablo 2. HPT'den elde edilen puanlar

\begin{tabular}{ccccccc}
\hline Öğrenci & Sınıf Düzeyi & HPT 1 & HPT 2 & HPT 3 & HPT 4 & HPT Sonucuna Göre Tespit Edlen Sınıf Seviyesi \\
\hline Ö1 & 5 & 17 & 29 & 62 & 37 & 2 \\
Ö2 & 5 & 13 & 22 & 52 & 37 & 1 \\
Ö3 & 5 & 7 & 9 & 23 & 26 & - \\
Ö4 & 5 & 16 & 23 & 45 & 30 & 2 \\
Ö5 & 5 & 17 & 29 & 64 & 43 & 1 \\
Ö6 & 6 & 15 & 24 & 48 & 32 & 1 \\
Ö7 & 6 & 12 & 18 & 46 & 35 & - \\
Ö8 & 6 & 9 & 15 & 31 & 21 & 1 \\
Ö9 & 7 & 10 & 19 & 52 & 41 & 4 \\
Ö10 & 7 & 40 & 80 & 199 & 198 & - \\
Ö11 & 7 & 9 & 19 & 51 & 39 & 3 \\
Ö12 & 8 & 23 & 45 & 104 & 72 & - \\
Ö13 & 8 & 9 & 15 & 43 & 37 & 3 \\
Ö14 & 8 & 3 & 8 & 24 & 20 & 1 \\
Ö15 & 8 & 24 & 42 & 106 & 94 & \\
Ö16 & 8 & 16 & 23 & 58 & 40 & \\
\hline
\end{tabular}

HPT sonuçlarına göre 5 öğrencinin 1. sınıf düzeyinin altında; 6 öğrencinin 1. sınıf düzeyinde; 2'şer öğrencinin 2. ve 3. sınıf düzeyinde son olarak 1 öğrencinin de 4. sınıf düzeyinde performans gösterdiği görülmektedir. Bu sonuçtan yola çıkılarak 1. sınıf ve altında performans gösteren toplam 11 öğrenciye MBT-1; 2 öğrenciye MBT-2; 2 öğrenciye MBT-3 ve 1 öğrenciye MBT-4 uygulanmıştr. Elde edilen verilere ait sonuçlar Tablo 3'te verilmiştir.

Tablo 3. MBT'den elde edilen puanlar

\begin{tabular}{ccccccc}
\hline Öğrenci & SInıf Düzeyi & MBT 1 & MBT 2 & MBT 3 & MBT 4 & MBT Sonucuna Göre Tespit Edlen SInıf Seviyesi \\
Ö1 & 5 & - & 9 & 1 & - & 2 \\
Ö2 & 5 & 10 & 5 & - & - & 1 \\
Ö3 & 5 & 5 & - & - & - & - \\
Ö4 & 5 & 9 & 7 & - & - & 1 \\
Ö5 & 5 & 9 & 5 & - & - & 1 \\
Ö6 & 6 & 7 & 3 & - & - & 1 \\
Ö7 & 6 & - & 8 & 3 & - & 2 \\
Ö8 & 6 & 4 & - & - & - & - \\
Ö9 & 7 & 7 & 7 & - & - & 1 \\
Ö10 & 7 & - & - & - & 23 & 4 \\
Ö11 & 7 & 8 & 8 & 2 & - & 2 \\
Ö12 & 8 & - & 9 & 3 & - & 2 \\
Ö13 & 8 & 7 & 5 & - & - & 1 \\
Ö14 & 8 & 4 & - & - & - & - \\
Ö15 & 8 & - & 9 & 4 & - & 2 \\
Ö16 & 8 & - & 8 & 3 & - & 2 \\
\hline
\end{tabular}

Tablo 3'te olduğu gibi MBT sonuçlarına göre öğrencilerin matematik başarısı açısından olmaları gerektiği sınıf düzeyinin oldukça altında olduğu görülmektedir. Araştırmaya katılan 16 öğrencinin MBT sonuçlarına bakıldığında sadece 1 öğrencinin 4. sınıf (bu öğrencinin HPT, MBT ve SDÖ ön testine ait tüm sonuçları beklenenin üzerinde çıktı̆ı için öğrenci 
araştırmanın deneysel kısmına dahil edilmemiştir), 6 öğrencinin 2. sınıf ve 9 öğrencinin de 1. sınıf ve daha altındaki bir düzeyde olduğu görülmektedir. Öğrenciler için genel olarak bulundukları sınıf düzeyinin en az 3 sınıf alttnda performans gösterdikleri söylenebilir. MBT'den elde edilen sonuçlar HPT ile karşılaştırıldı̆ında sonuçların örtüştüğü görülmektedir. Çünkü öğrencilerin tamamı HPT'nin çarpma ve bölme işlemlerini kapsayan kısımlarında zorlanmışlar ve bu işlemlerdeki eksiklerinden dolayı da MBT'nin 3. ve 4. sınıf versiyonunda zorlanmışlardır. Tablodaki MBT sonuçlarından yola çıkılarak testi alan öğrencilerin matematik öğrenme güçlügü çektikleri söylenebilir. Elde edilen sonuçlara göre öğrencilerin olması gereken sınıf düzeyinin kalmaları, alanyazında akranlarına göre en az iki sınıf geride matematik performansı gösteren öğrencilerin diskalkuli olarak değerlendirilebileceği (Semrud-Clikeman, Biederman, Sprich-Buckminster, Lehman, Faraone ve Norman, 1992) görüşüyle örtüşmektedir. MBT testinden elde edilen sonuçlara göre, araştırma kapsamına dahil edilen 16 öğrenciden 15 'inin matematik öğrenme güçlüğü yaşadığına karar verilmiştir. Araştırma kapsamı dışında kalan öğrenci deneysel sürece dahil edilmemiş böylece 15 öğrenci ile sayı konuşmaları uygulamalarına başlanmıştı. Deneysel sürecin SDÖ'den elde edilen puanlara olan etkisini test etmek üzere uygulanan ölçeğe ait ön test ve son test arasındaki fark puanlarının dağılımlarının normalliğine ilişkin test sonuçları ise Tablo 4'te verilmiştir.

Tablo 4. SDÖ fark puanlarının normallik testi

\begin{tabular}{cccccccc}
\hline & \multicolumn{3}{c}{ Kolmogorov-Smirnov } & \multicolumn{3}{c}{ Shapiro-Wilk } \\
& $\mathbf{X}$ & $\mathbf{s d}$ & $\mathbf{p}$ & $\mathbf{X}$ & sd & $\mathbf{p}$ \\
\hline Fark & .336 & 15 & .000 & .757 & 15 & .001 \\
\hline
\end{tabular}

Tabloda görüldüğü gibi SDÖ'den elde edilen ön test ve son teste ait fark puanları normal dağılmamaktadır. Gözlem sayısının 30'un altında olduğu durumlarda Shapiro-Wilk, önerilmektedir (Can, 2013). Burada veri sayısı 30'un altında olduğundan Shapiro-Wilk testi sonuçları kullanılmıştr. Test sonucu hesaplanan $p$ değerinin .01'den küçük olması normal dağılımla aralarında fark yoktur şeklindeki yokluk hipotezinin reddedilerek normalliğin sağlanmadığı anlamını taşımaktadır. Bu nedenle SDÖ'den alınan ön test ve son test puanlarını karşılaştırmak üzere nonparametrik bir test olan Wilcoxon İşaretli Sıralar testi kullanılmış ve test sonucu Tablo 5'te verilmiştir.

Tablo 5. SDÖ puanlarının karşılaştırılması

\begin{tabular}{cccccc}
\hline Son-Ön Test & $\mathbf{N}$ & Sıra Ortalaması & Sıra Toplamı & $\mathbf{z}$ & $\mathbf{p}$ \\
\hline Negatif Sıralar & 0 & .00 & .00 & -3.407 & .001 \\
Pozitif Sıralar & 14 & 7.50 & 105.00 & & \\
Fark Olmayan & 1 & & & & \\
Toplam & 15 & & & & \\
\hline
\end{tabular}

Tablo 5'e göre sayı konuşmaları uygulamalarının deneysel uygulama öncesi ve sonrasında elde edilen SDÖ puanları arasında istatistiksel olarak anlamlı bir fark yaratıp yaratmadığını ortaya koymak amacıyla yapılan Wilcoxon İşaretli Sıralar testinin sonucuna göre sayı konuşmaları uygulamalarına katılan ve matematik öğrenme güçlügü yaşayan 15 ortaokul öğrencisinin uygulama öncesi ve sonrasındaki SDÖ puanlarında istatistiksel olarak anlamlı bir fark gözlenmiştir [z=-3.407, p<.01]. Söz konusu fark son test lehine olduğu için sayı konuşmaları uygulamalarının matematik öğrenme güçlüğü yaşayan ortaokul öğrencilerinin SDÖ puanları üzerinde istatistiksel olarak anlamlı ve olumlu bir etkisinin olduğu söylenebilir. Ayrıca öğrencilerin yanıtları doğruluk durumunun yanı sıra kullandıkları stratejiler açısından da incelendiğinde ön testte kural temelli çözüm yolunu kullanan öğrencilerin çoğunun son testte sayı duyusu temelli çözüm yollarını keşfettiği görülmüştür. Örneğin 91+93+97+99 (Bkz: Şekil 1 ve Şekil 2) ve 39+23+52+48+61+77 sayılarının toplamının bulunmasının istendiği iki soruda çok sayıda öğrencilerin başlangıçta ilgili sayıları alt alta yazarak algoritmik toplama yaptıkları (örneğin, Bkz: Şekil 1 ve Şekil 3), sayı konuşmaları uygulamalarından sonra ise birbirini 10’a tamamlayan birliklerden başlayarak toplama yapma eğiliminde oldukları (örneğin, Bkz: Şekil 2 ve Şekil 4) görülmüştür. Bu bulgu öğrencilerin sayılar arası ilişkileri fark ederek kalıcı hesaplama yapabildiklerine dair bir göstergedir. Araştırmanın bu bulguları diskalkulik öğrencilerin yapılan öğretimsel müdahale karşııında gösterdikleri gelişim açısından alanyazındaki çalışmaların bulguları ile benzerlik göstermektedir (Beygi, Padakannaya ve Gowramma, 2010; Doğmaz, 2016; Dorudian, 2011; Khan, 2013; Siadatian ve Gharamani, 2013; Zerafa, 2015). Aynı iki öğrencinin ön test ve son testte yapttkları çözümlere iliş̧in birkaç örnek şu şekildedir:
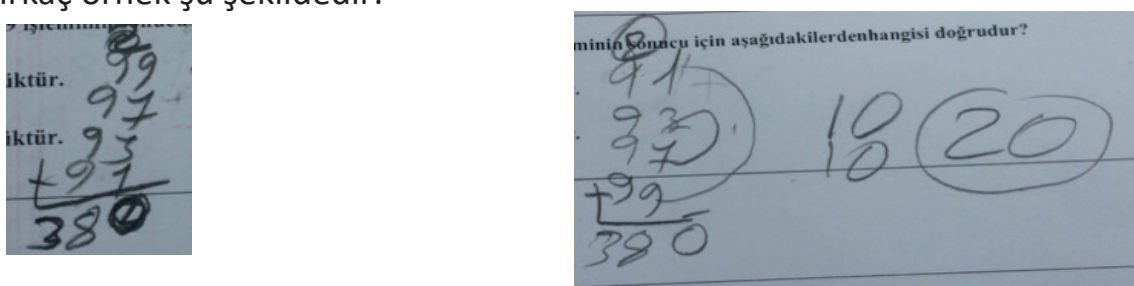

Şekil 1. Ön testte yer alan bir çözüm

Şekil 2. Son testte yer alan bir çözüm

| Kastamonu Eğitim Dergisi, 27(6), 2019| 


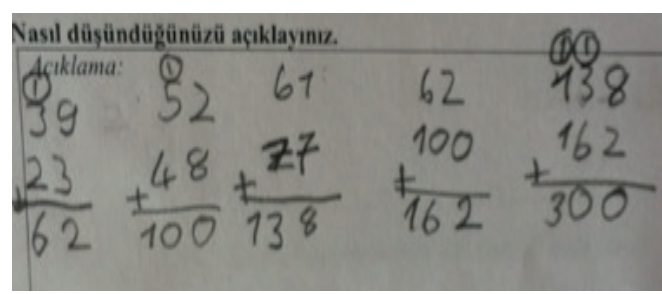

Şekil 3. Ön testte yer alan bir çözüm

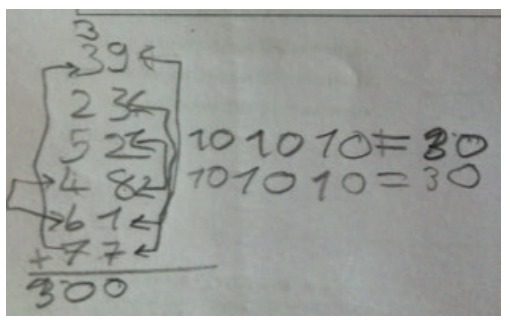

Şekil 4. Son testte yer alan bir çözüm

Şekillerde de görüldüğü gibi öğrenciler uygulama sonrasında daha makul çözümler üretebilmişlerdir Öğretim sürecine ilişkin gözlemler

Öğrenciler toplama işlemlerinde sürekli parmaklarını kullanarak sayma yaptıkları için yuvarlama ve toplamı 10 yapan sayılarla ilgili işlemlerin gelişimi zaman almıştır. Şipşak sayılama ile ilgili alıştırmalarda başlangıçta öğrencilerin yanlış yapmamak için noktaları tek tek sayarak cevaplama eğiliminde oldukları daha sonra ise gruplama yaparak saydıkları ve doğru cevaba daha çabuk ulaştkları görülmüştür. Benzer şekilde $2+5+8$ gibi üçlü toplamalarda toplamı 10 yapan sayıları gruplamayı gerektiren durumlarda öğrencilerin neredeyse tamamı başlangıçta parmaklarını kullanırken süreç sonunda tüm öğrenciler toplamı 10 yapan sayılar olup olmadığına bakmaya başlamıştr. Son aşamada da öğrencilerin birçoğu dört ve beş sayıdan meydana gelen toplamlarda da akıcı hale gelmişlerdir. Öğrencilerin çarpmanın alt yapısını oluşturan tekrarı toplamanın (4+4, 5+5 gibi) mantı̆ııı kavramaları amacıyla incelenen örneklerde sonu sıfirla biten $(10+10,20+20$ gibi) toplamları kolaylıkla cevaplayabiliyorken diğer toplamları aynı akıcııkta yapamadıkları görülmüştür. Öğrencilerin dönüşüm yapmayı gerektiren toplamalarda (örneğin $4+6$ 'yı 5+5'e çevirme gibi) çok zorlandıkları ve bu türden örneklere devam etmek istemedikleri gözlemlenmiş, öğrencilerin başarısız olma kaygısıyla olumsuz tutum geliştirmelerinin önüne geçmek amacıyla devam etmek istemedikleri an çalışma sonlandııılmış ya da öğrencinin yapmaktan hoşlandığı alıştırmalara benzer alıştırmalar üzerinde tekrar çalışılmıştr. Bu nedenle sayı konuşmaları uygulamaları deneysel sürecin çok kısa olması nedeniyle de 1-2. sınıf düzeyinde gerçekleştirilebilmiş 3-5. sınıf düzeyindeki uygulamalara öğrencilerin hazırbulunuşlukları yeterli olmadıı̆ı için geçilememiştir.

\section{Sonuçlar}

Öğretim sürecinin başında öğrencilerin diskalkuli göstergelerinden biri olan parmak kullanarak sayma yaptıkları ve şipşak sayılamada zorluk yaşadıkları görülmektedir. Araştırmanın sonunda ise bu tür davranışların azaldığı fakat birkaç öğrencinin hala parmakla saymaya devam ettiği görülmüştür. Bu durum Emerson ve Babtie (2010) ve Bird (2009)'un ilkokuldan sonra, ilerleyen sınıf ve işlem düzeyine rağmen ısrarla parmak kullanarak saymanın diskalkuli belirtisi olarak düşünülebileceğini öne süren açıklamalarıyla örtüşmektedir. Ayrıca sayı konuşmaları uygulamalarıyla öğrencilerin toplama ve çıkarma işlemlerine yönelik performanslarının arttı̆ı ve bu bulgunun alanyazındaki çalışmalarla (Beygi, Padakannaya ve Gowramma, 2010) paralellik gösterdiği görülmüştür. Çalışmaya katılan öğrencilerin yaşadıkları süreğen başarısızlık nedeniyle çok çabuk pes etme eğilimi gösterdikleri bu araştırma boyunca da gözlemlenmiştir (Abigail, 2007; Ramezani, 2004). Aynı öğrencilerin başarılı oldukları zaman bir üst aşamaya geçmek için çaba sarf ettikleri de (Bkz: Ö1; Tablo 1) araştırmanın dikkate değer bir bulgusudur. Buradan yola çıkılarak gereken önlemler alınıp öğrencilerin ihtiyaçlarına uygun müdahaleler yapıldığında matematik öğrenme güçlüğü yaşayan öğrencilerin matematiğe ilişkin bilişsel ve duyuşsal özelliklerinde olumlu yönde değişimin gözlenebileceği söylenebilir. Bu çalışmada kullanılan bir öğretimsel araç olan sayı konuşmaları uygulamalarının, matematik öğrenme güçlüğü yaşayan ortaokul öğrencilerine 3 hafta gibi kısa bir süreyle uygulanmasıyla bile öğrencilerin sayı duyusu ölçeğinden aldıkları puanları istatistiksel olarak anlamlı derecede ve olumlu yönde etkilediği görülmüştür. Bu sonuçtan yola çıkılarak sayı duyusu temelinde yaşanan zorluklarla bağlantılı olan matematik öğrenme güçlüğüne dair sorunların giderilebilmesi açııından sayı konuşmaları uygulamalarının işlevsel ve faydalı bir öğretimsel araç olma potansiyeli dikkat çekmektedir.

Diskalkulik öğrencilerin yapılan müdahale sonrasında matematiksel becerilerinde meydana gelen olumlu değişime ilişkin araştırmanın bu bulgusu alanyazındaki çalışmalarla örtüşmekte ve (Beygi, Padakannaya ve Gowramma, 2010; Chiappini, Cozzani, Verna, Potente ve De Carli, 2016; Doğmaz, 2016; Khan, 2013; Kucian vd., 2011; Maryam, Mahnaz ve Hasan, 2011; Zerafa, 2015) yapılan müdahalelerin olumlu etkisini ve önemini tekrar ortaya koymaktadır. Bu gibi özel gereksinimleri olan öğrencilerin gereksinimlerinin yeterince karşılanamaması durumunda zamanla okuldan koptukları hatta okulu bıraktikları (Cortiella ve Horowitz, 2014) göz önünde bulundurulursa bu türden müdahalelerin önemi daha çok anlaşılmaktadır. Ayrıca bu tür öğrencilerin kaçınma stratejisi olarak geliştirebileceği sık sık tuvalate gitme, kalem açma vb. gibi davranışların (Krinzinger ve Kaufmann, 2006; Akt: Kaufmann ve von Aster, 2012) bir süre sonra sınıf içi atmosferi de bozarak kendisiyle birlikte diğer arkadaşlarının ve öğretmenlerinin de verimli bir ders işlemesine engel teşkil edeceği öngörülebilir sonuçlardandır. Sürekli başarısız olan öğrencilerin başarısızlık nedenlerinin matematik öğretiminin yetersizliğinden mi yoksa öğrenme güçlüğünden mi kaynaklandığı tam olarak ayırt edilemediği için (Van De Walle, Karp ve Bay-Williams, 2016) de 
bu türden özel gereksinimleri olan öğrencilere yapılacak bireysel destek eğitimlerinin işlevi daha önemli hale gelmektedir.

\section{5. Öneriler}

Özel eğitime verilen önemin hem ülkemiz hem de dünyadaki uygulamalar ve araştrrmalarla her geçen gün artması sevindirici bir gelişme olmakla birlikte özel gereksinimli öğrencilerin eğitimsel ve öğretimsel ihtiyaçlarının bilimsel yaklaşımlar ve uygun öğretimsel araçların farkında olunarak yapılması gerek öğretmenleri gerekse de öğrencilerin süreçten daha fazla fayda ve verim elde etmelerine katkı sağlayacaktır. Bu da ancak öğrenme güçlüğü yaşayan öğrencilerin matematiği anlamaları için en uygun yolların araştrıımasıyla mümkündür (Guillemot, 2002). Zira öğrenme güçlüğü yaşayan öğrencilere yardım elini ilk uzatacak olan öğretmenlerin ve geleceğin öğretmenleri olan öğretmen adaylarının matematik öğrenme güçlüğüne ve sayı duyusuna dair bilgi düzeylerinin istenen seviyede olmayışı (Can ve Durmaz, 2016; Hacısalihoğlu Karadeniz, 2013; Sezer ve Akın, 2011) sınıf içinde ve dışında verilebilecek desteğin niteliği ve etkisi hakkında düşündürücüdür. Bu nedenle nitelikli ve ihtiyaca cevap veren bir öğretim hizmetinin sunulabilmesi için öğretmen adayları ve öğretmenlerin diskalkuli ve sayı duyusuna ilişkin farkındalıkları tespit edilerek ortaya çıkan tablo sonrasında gerekli önlemlerin alınması sağlanabilir.

Bu araştırmada etkisi test edilen sayı konuşmaları uygulamalarının matematik eğitimine özgü bir öğretimsel araç olması, diğer müdahale türleri ve araçlarına göre özel eğitime dair alan ve uzmanlık bilgisi gerektirmemesi gibi nedenlerle matematik ve sınıf öğretmenleri tarafindan kullanılmasının daha avantajlı olabileceği söylenebilir. Bu öğretimsel aracın ekstra bir eğitim ve maliyet getirmiyor oluşu da yine onu daha kullanışlı ve tüm öğretmenler tarafindan erişilebilir kılmaktadır. Matematik dersi genelinde diskalkulik öğrencilere yardımcı olmak amacıyla bu tür öğretimsel araçları kullanmanın yanı sıra çok adımlı problemleri daha küçük parçalara ayırma; duvarlara kısa süreli belleğe hemen getirilemeyecek temel kavramlara ait posterler asma; hafizada tutmaya yardımcı kartlar kullanma ve bir sorunun çeşitli bölümlerini renklendirme gibi çalışmalar yapılması da tavsiye edilmektedir (Trott, 2003). Kısaca matematik öğrenme güçlüğü yaşayan öğrencilere uygun şekilde ve zaman kaybetmeden müdahale etmenin önemi ve değerinin (Gifford, 2006) azımsanmaması ile atılacak her adım eğitim hakkına erişim ve eşitlik ilkelerinin eğitim ortamlarında somut olarak vücut bulmasında hayati bir role sahip olabilir.

Son olarak bu araştırmanın sınırlılıkları değerlendirildiğinde araştırmanın kısa bir zaman diliminde, aynı eğitim kademesinde ve az sayıda öğrenci ile yürütülmüş olduğu görülmektedir. Daha sonra yapılacak çalışmalar daha uzun süreli, daha kapsamlı ve derinlemesine bilgi sağlayacak şekilde tasarlanarak sayı konuşmaları uygulamalarının veya başka öğretimsel araç, yöntem ya da tekniklerin etkileri test edilebilir. Ayrıca matematik öğrenme güçlüğü yaşayan öğrenciler için yapılan müdahalelerin uzun vadeli ya da kalııı olabilecek sonuçları ve matematiğe yönelik tutum, akademik benlik ve motivasyon vb. gibi bilişsel ve duyuşsal özelliklerinde meydana gelen değişimler de incelenebilir.

\section{Kaynakça}

Abigail, N. J. (2007). Gender differences and the teaching of mathematics, Inquiry, 12(1), 14-25.

Alkaş Ulusoy, Ç., \& Şahiner, Y. (2017). Sayı duyusuna yönelik özyeterlilik ölçeğinin geliştirilmesi. Kastamonu Eğitim Dergisi, 25(1), 17-32.

Al-Makahleh, A. A. (2011). The effect of direct instruction strategy on math achievement of primary 4th and 5th grade students with learning difficulties. International Education Studies, 4(4), 199-205.

Ardilla, A., \& Rosselli, M. (2002). Acalculia and dyscalculia. Neuropsychology Review, 12(4), 179-231.

Bayram, G. (2013). 8. sınıf öğrencilerinin üslü ifadelere ilişkin sayı duyuları ve başarıları arasındaki ilişki. Doktora tezi, Pamukkale Üniversitesi.

Bevan, A., \& Butterworth, B. (2007). The responses to maths disabilities in the classroom. www.mathematicalbrain.com/pdf/2002BEVANBB.PDF adresinden erişilmiştir.

Beygi, A., Padakannaya, P., \& Gowramma, I. (2010). A remedial intervention for addition and subtraction in children with dyscalculia. Journal of the Indian Academy of Applied Psychology, 36, 9-18.

Bird, R. (2009). Overcoming difficulties with number: Supporting dyscalculia and students who struggle with maths. London: Sage.

Butterworth, B. (2010). Foundational numerical capacities and the origins of dyscalculia. Trends in Cognitive Sciences, 14(12), 534-541.

Butterworth, B., \& Yeo, D. (2004). Dyscalculia guidance. London: nferNelson.

Büttner, G., \& Hasselhorn, M. (2011). Learning disabilities: debates on definitions, causes, subtypes, and responses. International Journal of Disability, Development and Education, 58(1), 75-87.

Büyüköztürk, Ş., Kılıç Çakmak, E., Akgün, Ö. E., Karadeniz, Ş., \& Demirel, F. (2012). Bilimsel araştırma yöntemleri. Ankara: Pegem Akademi.

Can, A. (2013). SPSS ile bilimsel araştırma sürecinde nicel veri analizi, Ankara: Pegem Akademi.

Can, D. (2017). Illkokul dördüncü sınıföğrencilerinin sayı duyularının bağlam temelli ve bağlam temelli olmayan problem durumlarında incelenmesi, Doktora tezi, Hacettepe Üniversitesi.

Can, D., \& Durmaz, B. (2016). Effects of number talks of preservice primary teachers, International Conference on Education in Mathematics, Science and Technology (ICEMST)'te sunulan bildiri, 59, Bodrum. Erişim adresi: https://www.2016.icemst.com/ICEMST2016_Proceeding_Book. pdf? rnd $=1383877097$

| Kastamonu Eğitim Dergisi, 27(6), 2019| 
Castro, M. V., Bissaco, M.A.S., Panccioni, B. M., Rodrigues, S. C. M., \& Domingues, A. M. (2014). Effect of a virtual environment on the development of mathematical skills in children with dyscalculia. PLoS ONE, 9(7): e103354. DOI:10.1371/journal.pone.0103354

Chiappini, G., Cozzani, G., Verna, S., Potente, C., \& De Carli, F. (2016). An educational method for evaluating the resistance to the treatment in the diagnosis of dyscalculia. Form@ re-Open Journal per la formazione in rete, 16(1), 37-54.

Chideridou-Mandari, A., Padeliadu, S., Karamatsouki, A., Sandravelis, A., \& Karagiannidis, C. (2016). Secondary mathematics teachers: what they know and don't know about dyscalculia. International Journal of Learning, Teaching and Educational Research, 15(9), 84-98.

Chinn, S. (2004). The trouble with maths: A practical guide to helping learners with numeracy difficulties. Routledge.

Chodura, S., Kuhn, J. T., \& Holling, H. (2015). Interventions for children with mathematical difficulties: A meta-analysis. Zeitschrift für Psychologie, 223, 129-144. DOI: 10.1027/2151-2604/a000211

Cortiella, C., \& Horowitz, S. H. (2014). The state of learning disabilities: Facts, trends and emerging issues. New York: National Center for Learning Disabilities.

Çelikağ, ì. (2015). Matematik öğrenme güçlüğü (diskalkuli) hastaları ve sağlıkı kontrollerde sayı işleme performansının değerlendirilmesi, Yüksek lisans tezi, Ankara Üniversitesi.

De Vos, T. (1992). TTR Tempotest rekenen [Arithmetic number fact test]. Lisse, The Netherlands: Swets \& Zeitlinger.

Doğmaz, S. (2016). Özel öğrenme güçlüğü olan öğrencilerin iki basamaklı rutin problemleri çözme performanslarını geliştirmede diyagram yöntemi kullanımının etkililiği. Yüksek lisans tezi, Dokuz Eylül Üniversitesi.

Dorudian, Z. (2011). The impact of role-playing technique on social adjustment and academic achievement in dyscalculia students of Tehran province, academic year 87-88, Quarterly Psychology of Exceptional Individuals, 1(2), 85-101.

Dowker, A. D. (2004). What works for children with mathematical difficulties? London: DfES.

Emerson, J., \& Babtie, P. (2010). The dyscalculia assessment. Bloomsbury Publishing.

Erden, G. (2011). Özgül öğrenme güçlüğü. İstanbul Eğitim ve Kültür Dergisi, 4(4), 60-65.

Fidan, E. (2013). İlkokul öğrencileri için matematik dersi sayılar öğrenme alanında başarı testi geliştirilmesi. Yüksek lisans tezi, Ankara Üniversitesi.

Flick, M., \& Kuchey, D. (2015). Contest corner: increasing classroom discourse and computational fluency through number talks. Ohio Journal of School Mathematics, 71, 39-41.

Fu, S. H., \& Chin, K. E. (2017). An online survey research regarding awareness of dyscalculia among educators in Sandakan district, Sabah. International Journal of Academic Research in Progressive Education and Development, 6(2), ISSN: 2226-6348.

Geary, D.C. (2006). Dyscalculia at an early age: characteristics and potential influence on socio-emotional development. Encyclopedia on Early Childhood Development, 15, 1-4.

Gifford, S. (2006). Dyscalculia: myths and models, Research in Mathematics Education, 8(1), 35-51, DOI: 10.1080/14794800008520157

Gifford, S., \& Rockliffe, F. (2012). Mathematics difficulties: does one approach fit all?, Research in Mathematics Education, 14(1), 1-15, DOI: $10.1080 / 14794802.2012 .657436$

Gillum, J. (2014). Assessment with children who experience difficulty in mathematics. Support for Learning, 29(3), $275-291$.

Gray, E., \& Tall, D. (1994). Duality, ambiguity, and flexibility: A "proceptual” view of simple arithmetic. Journal for Research in Mathematics Education, 25(2), 116-140.

Guillemot, T. (2002). Dyscalculia-an overview of research on learning disability. Teacher Education Programme, Mathematics and Computing. http://www.idt.mdh.se/kurser/ct3340/ht09/ADMINISTRATION/IRCSE09submissions/ircse-09_submission_25.pdf adresinden erişilmiştir.

Hacısalihoğlu Karadeniz, M. (2013). Diskalkuli yaşayan öğrencilere ilişkin öğretmen görüşlerinin değerlendirilmesi. E-Journal of New World Sciences Academy Social Sciences. 8(2),193-208.

Halberda, J., Ly, R., Wilmer, J. B., Naiman, D. Q., \& Germine, L. (2012). Number sense across the lifespan as revealed by a massive internet-based sample. Proceedings of the National Academy of Sciences, 109(28), 11116-11120.

Hannell, G. (2013). Dyscalculia: action plans for successful learning in mathematics. Routledge.

Ho, C. S., Wong, T. T., \& Chan, W. W. L. (2015). Mathematics learning and its difficulties among Chinese children in Hong Kong. In S. Chinn (Ed.) (2015), The Routledge International Handbook of Dyscalculia and Mathematical Learning Difficulties. London, United Kingdom: Routledge.

Humphreys, C., \& Parker, R. (2015). Making number talks matter: Developing mathematical practices and deepening understanding, grades 4-10. Stenhouse Publishers.

İşçil, N. (1973). İstatistik metodları ve uygulamaları, Ankara: AITIA Yayınları.

Kaufmann, L., \& von Aster, M. (2012). The diagnosis and management of dyscalculia. Deutsches Ärzteblatt International, 109(45), 767-778.

Kayhan Altay, M., \& Umay, A. (2013). Illköğretim ikinci kademe öğrencilerine yönelik sayı duyusu ölçeğinin geliştirilmesi. Eğitim ve Bilim, $38(167), 242-255$.

Khan, S. (2013). Evaluating the effectiveness of response to intervention in ela and math for sixth, seventh, and eighth grade students, Master's Thesis. Louisiana State University, USA.

Krinzinger, H., \& Kaufmann, L. (2006). Rechenangst und Rechenleistung. Sprache, Stimme, Gehör, 30, 160-4.

Kroesbergen, E., \& van Luit, J.E.H. (2003). Mathematics intervention for children with special educational needs. Remedial and Special Education, 24, 97-114.

Kucian, K., Grond, U., Rotzer, S., Henzi, B., Schönmann, C., Plangger, F., vd. (2011). Mental number line training in children with developmental dyscalculia. Neuroimage, 57(3), 782-795.

| Kastamonu Eğitim Dergisi, 27(6), 2019| 
Landerl, K., Bevan, A., \& Butterworth, B. (2004). Developmental dyscalculia and basic numerical capacities: A study of 8-9-year-old students. Cognition, 93(2), 99-125.

Maryam, A., Mahnaz, E., \& Hasan, A. (2011). Comparing the impact of number sense on mathematics achievement in both dyscalculia and normal students. Procedia-Social and Behavioral Sciences, 28, 5-9.

McIntosh, A., Reys, B. J., \& Reys, R. E. (1992). A proposed framework for examining basic number sense. For the Learning of Mathematics, 12 (3), 2-9.

Milli Ĕğtim Bakanlığı (MEB). (2009). illköğretim matematik 6-8. sınıflar öğretim programı kitabı, Ankara.

Mutlu, Y. (2016). Matematik öğrenme güçlüğü yaşayan öğrencilerin sayı algılama becerileri üzerindeki etkilerinin incelenmesi. Doktora tezi. Atatürk Üniversitesi.

Mutlu, Y. ve Akgün, L. (2017). Matematik öğrenme güçlüğünü tanılamada yeni bir model önerisi: çoklu süzgeç modeli. Illköğretim Online, 16(3), 1153-1173.

National Council of Teachers of Mathematics. (2000). NCTM standards 2000: Principles and standards for school mathematics. Reston, VA: NCTM.

Olkun, S., Can, D. ve Yeşilpınar, M. (2013). Hesaplama performansı testi: geçerlilik ve güvenilirlik çalışması. USOS 2013 Ulusal Sınıf Öğretmenliği Eğitimi Sempozyumu'nda sunulan bildiri. Aydın.

Olkun, S. (2015). 6-11 Yaş Türk Çocukları Örnekleminde Diskalkuliye Yatkınlığı Ayırt Etmede Kullanılacak Bir Ölçme Aracı Geliştirme Çalışması. 111 k545 Nolu TÜBiTAK Projesi, Ankara, Türkiye.

Ölmez, Y., \& Argün, Z. (2017). RTI modelinin özel eğitime gereksinimi olan 5. sınıf öğrencilerinin matematik öğrenmeleri üzerindeki etkililiği, Eğitim ve Bilim, 42(190). 89-106.

Parish, S. (2014). Number talks helping children build mental math and computation strategies (2nd ed.). Sausalito, CA: Math Solutions.

Pellerone, M. (2013). Identity status, coping strategy and decision making process among italian university students. Procedia-Social and Behavioral Sciences, 106, 1399-1408.

Price, G. R. \& Ansari, D. (2013). Dyscalculia: characteristics, causes, and treatments. Numeracy, 6(1), 1-16.

Rababah, A., \& Alghazo, Y. (2016). Diagnostic assessment and mathematical difficulties: an experimental study of dyscalculia. Open Journal of Social Sciences, 4(06), 45-52.

Rajaie, H., Allahvirdiyani, K., Khalili, A., \& Sadeghi, A. (2011). Effect of teaching attention to the mathematic performance of the students with dyscalculia in the third and fourth grade of elementary school. Procedia-Social and Behavioral Sciences, 15, 3024-3026.

Ramezani, M. (2004). The analysis of calculation errors in students with dyscalculia, Research on Exceptional Children, 3(3-4), $223-244$.

Reeve, R. A., \& Humberstone, J. (2012). Dyscalculia in young children: Cognitive and neurological bases. İçinde N. M. Seel (Ed.) Encyclopedia of the Sciences of Learning, 1062-1065, New York: Springer. DOI: 10.1007/978-1-4419-4286-725.

Reys, R., Reys, B., McIntosh, A., Emanuelsson, G., Johansson, B., \& Yang, D. C. (1999). Assessing number sense of students in Australia, Sweeden, Taiwan, and the United States. School Science and Mathematics, 99(2), 61-70.

Rubinsten, O., \& Tannock, R. (2010). Mathematics anxiety in children with developmental dyscalculia. Behavioral and Brain functions, 6(1), 1-13.

Ruter, K. (2015). Improving number sense using number talks, Master's Thesis, Dordt College.

Salman, U., Özdemir, S., Salman, A. B. ve Özdemir, F. (2016). Özel öğrenme güçlüğü “Disleksi”. FNG \& Bilim Tip Dergisi, 2(2):170-176 DOI: 10.5606/ fng.btd.2016.031

Semrud-Clikeman, M., Biederman, J., Sprich-Buckminster, S., Lehman, B. K., Faraone, S. V., \& Norman, D. (1992). Comorbidity between ADDH and learning disability: A review and report in a clinically referred sample. Journal of the American Academy of Child \& Adolescent Psychiatry, 31(3), 439-448.

Sezer, S. ve Akın, A. (2011). 6-14 yaş arası öğrencilerde görülen matematik öğrenme bozukluğuna ilişkin öğretmen görüşleri. illköğretim Online, 10(2), 757-775.

Shalev, R. S., \& Gross-Tsur, V. (2001). Developmental dyscalculia. Pediatric Neurology, 24(5), 337-342.

Siadatian, S. H., \& Ghamarani, A. (2013). Meta-analysis of effectiveness of psychological-educational interventions on academic performance on dyscalculia students, Journal of Psychological Researches, 5(18), 85-97.

Swanson, H. L., \& Sachse-Lee, C. (2000). A meta-analysis of single subject design intervention research for students with LD. Journal of Learning Disabilities, 33, 114-136.

Trott, C. (2003). Mathematics support for dyslexic students. MSOR Connections, 3(4), 17-20.

Tuchura, D. G. (2016). Analysis of teachers' remedial strategies for enhancing mathematics skills to learners with dyscalculia in regular primary schools in Nyandarua Country, Kenya. Master's Thesis, Kenyatta University.

Van de Walle, J.A., Karp, K.S., \& Bay-Williams, J. M. (2016). Elementary and middle school mathematics teaching developmentally, (9th Ed.). Boston: Pearson.

Wadlington, E. M., Wadlington, P. L., \& Rupp, D. E. (2006). Effects of dyslexia and dyscalculia on teachers. Academic Exchange Quarterly, 10(3), $270-277$.

Zerafa, E. (2011). Helping children with dyscalculia: a teaching programme with three primary school children, Master's Thesis, Faculty of Education, University of Malta.

Zerafa, E. (2015). Helping children with dyscalculia: a teaching programme with three primary school children. Procedia-Social and Behavioral Sciences, 191, 1178-1182. 